Marta Worona', Michalina Nowakowska², Olga Fudalej², Patrycja Przybylska', Agata Tuczyńska'

\title{
Transmigracja kła dolnego - opis przypadku
}

\section{Transmigration of impacted lower canine - a case report}

\author{
${ }^{1}$ Katedra i Klinika Ortopedii Szczękowej i Ortodoncji, Uniwersytet Medyczny im. Karola Marcinkowskiego w Poznaniu \\ Chair and Department of Maxillofacial Orthopaedics and Orthodontics, Poznan University of Medical Sciences \\ ${ }^{2}$ Studenckie Koło Naukowe Ortopedii Szczękowej i Ortodoncji, \\ Uniwersytet Medyczny im. Karola Marcinkowskiego w Poznaniu \\ Students Scientific Association of Maxillary Orthopaedics and Orthodontics, Poznan University of Medical Sciences
}

DOI: http://dx.doi.org/10.20883/df.2020.20

\begin{abstract}
STRESZCZENIE
Transmigracja kła dolnego jest rzadką anomalią zębową polegającą na przekroczeniu przez kieł linii pośrodkowej żuchwy. Wśród metod leczenia wymienia się: ekstrakcję zęba zatrzymanego, autotransplantację lub ortodontyczne wprowadzenie zęba do łuku zębowego. W przypadku opisanej pacjentki podjęto decyzję o ortodontycznym wprowadzeniu zęba zatrzymanego do łuku. Za podjęciem leczenia przemawiała dobra współpraca z rodzicami, stopień I zatrzymania kła według Mupparapu, a także bezpieczna odległość od korzeni zębów sąsiednich.

Słowa kluczowe: transmigracja, dolny kieł, kieł żuchwy.

ABSTRACT

Lower canine transmigration is a rare dental anomaly where the canine crosses the mandibular midline. Treatment methods include: extraction of the impacted tooth, autotransplantation or orthodontic insertion of the tooth into the dental arch. In the presented case a decision was made to insert the impacted tooth orthodontically into the arch. Good cooperation with parents, Mupparapu grade I canine retention and a safe distance from the roots of adjacent teeth spoke in favor of taking the treatment.
\end{abstract}

Keywords: transmigration, lower canine, mandibular canine.

\section{Wstęp}

Transmigracja kła dolnego występuje, gdy kiełprzekroczy linię pośrodkową żuchwy. Częstość występowania waha się od 0,14\%-0,31\% [1, 2]. Ciężkość zaawansowania transmigracji opisuje skala Mupparapu - typ I występuje, gdy korona kła dolnego częściowo przekracza linię pośrodkową i znajduje się wargowo lub językowo w stosunku do siekaczy dolnych. Typ I jest najczęstszy. Typ II - kieł jest zatrzymany poziomo, poniżej wierzchołków korzeni siekaczy dolnych, blisko dolnej krawędzi żuchwy. Typ III - kieł wyrznął się mezjalnie lub dystalnie w stosunku do kła strony przeciwnej. Typ IV - kieł jest zatrzymany poziomo, blisko dolnej krawędzi żuchwy poniżej wierzchołków korzeni zębów przedtrzonowych i trzonowych strony przeciwnej. Typ V - usytuowany pionowo w linii pośrodkowej [3]. Badania Howarda i wsp. wykazały, że niewyrznięte kły leżące pod kątem 25-30 stopni w stosunku do płaszczyzny pośrodkowej nie mają tendencji do migrowania na stronę przeciwną, kły leżące pod kątem 30-95 stopni mają tendencję do migrowania i przekraczania linii pośrodkowej, a kiedy kąt nachylenia kła zwiększy się do 50 stopni migracja z przekroczeniem linii pośrodkowej staje się regułą [4]. Transmigracja kła częściej występuje po lewej stronie żuchwy niż po prawej oraz częściej u kobiet niż u mężczyzn (1,6:1) [5].

\section{Opis przypadku}

9-letnia pacjentka zgłosiła się do Poradni/Katedry i Kliniki Ortopedii Szczękowej i Ortodoncji UM w Poznaniu, skierowana z Poradni/ Katedry Stomatologii Dziecięcej. Pantomogram wykonany u pacjentki wykazał przekroczenie linii pośrodkowej przez ząb 33. Celem zaplanowania dalszego leczenia poszerzono diagnostykę o badanie $\mathrm{CBCT}$, które wykazało wargowe położenie zęba w bezpiecznej 
odległości od korzeni zębów siecznych dolnych. Pacjentka wykazywała dobrą higienę jamy ustnej, nie stwierdzono u niej chorób ogólnych. Kieł zaklasyfikowano jako stopień I Mupparapu. Współpraca zarówno z pacjentką jak i rodzicami była bardzo dobra. Przedstawiono następujące możliwości leczenia w oparciu o uprzednio wykonany przegląd piśmiennictwa: ekstrakcja zęba 33, autotransplantacja zęba 33 w miejsce biorcze po zębie 73, ortodontyczne wprowadzenie zęba 33 do łuku zębowego. Przedstawiono wady i zalety poszczególnych rozwiązań. Rodzice pacjentki zdecydowali się na opcję ortodontyczną, znając możliwe powikłania. Następnie założono aparat stały cienkołukowy na zęby w żuchwie i rozpoczęto fazę niwelacji. Dla wzmocnienia zakotwienia został zacementowany łuk podjęzykowy. Po kilku miesiącach chirurg stomatologiczny wykonał odsłonięcie kła, do którego przyklejono eylet i połączono z ligaturą metalową, do której została dołączona zamknięta sprężynka NiTi i zaczepiona o haczyk samozaciskowy na łuku SS $17 \times 25$. Podczas wizyt kontrolnych wymieniano ligatury oraz skracano sprężynę. Terapia ortodontyczna jest prowadzona nadal. Rodzice pacjentki zostali poinformowani, że w przypadku braku postępu leczenia ortodontycznego bądź wystąpienia resorpcji zębów sąsiednich istnieje możliwość demontażu aparatu i wykonania ekstrakcji zęba.

\section{Dyskusja}

W piśmiennictwie zalecana jest ekstrakcja kła z transmigracją [6-8]. Za stosowaną w piśmiennictwie metodę leczenia uważa się również wykonanie autotransplantacji, której powodzenie jest najwyższe w wieku pacjenta 8-9 lat [9], przeszczepienie transmigrowanego zęba w miejsce biorcze wiąże się z koniecznością następowego leczenia endodontycznego, a także częstych wizyt kontroInych [9]. Choć autotransplantacja jest zabiegiem opisywanym w piśmiennictwie [9], z uwagi na niepewne długoterminowe rokowanie, a także ryzyko powikłań w postaci resorpcji lub ankylozy, niewielu chirurgów podejmuje się wykonania tego zabiegu [9]. Rodzice pacjentki z uwagi na wysoki koszt zabiegu, a także konieczność częstych wizyt kontrolnych w Warszawie po zabiegu, nie zgodzili się na wykonanie tej procedury. Na podstawie istniejących doniesień naukowych dotyczących leczenia ortodontycznego transmigracji kła ustalono możliwe do wystąpienia powikłania - przewlekłość leczenia (w publikacji Cavuoti i wsp., wyniosła 3 lata i 6 miesięcy), ryzyko resorpcji korzeni zębów sąsiednich, brak efektu leczenia, nachylenie i nad- wrażliwość zębów sąsiednich [6]. Wszystkie powikłania przedstawiono rodzicom pacjentki, jak również to, że $w$ razie niepowodzenia terapii leczenie może zakończyć się ekstrakcją zęba 33. Za podjęciem leczenia ortodontycznego przemówiły takie czynniki, jak: bardzo dobra współpraca z pacjentką i jej rodzicami, stopień I Mupparapu położenia kła, wykazana w badaniu CBCT bezpieczna odległość w stosunku do wierzchołków korzeni zębów siecznych.

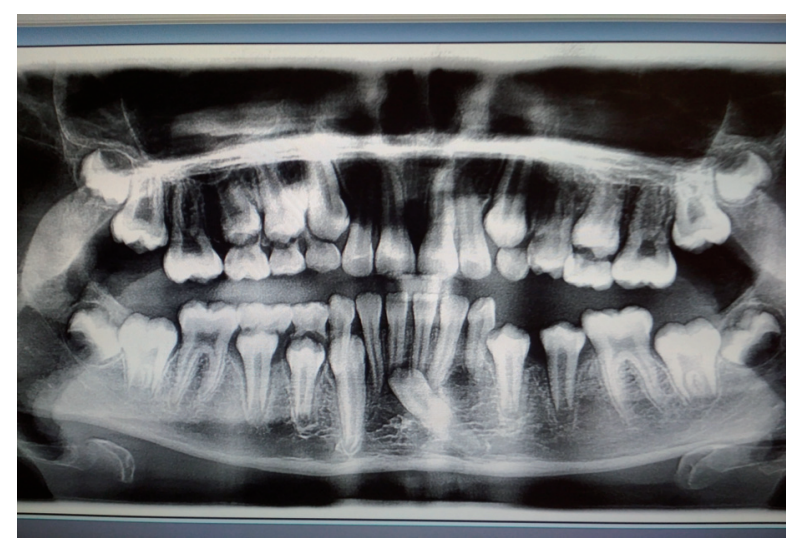

Rycina 1. Pantomogram przed rozpoczęciem terapii ortodontycznej

Figure 1. OPG before orthodontic treatment

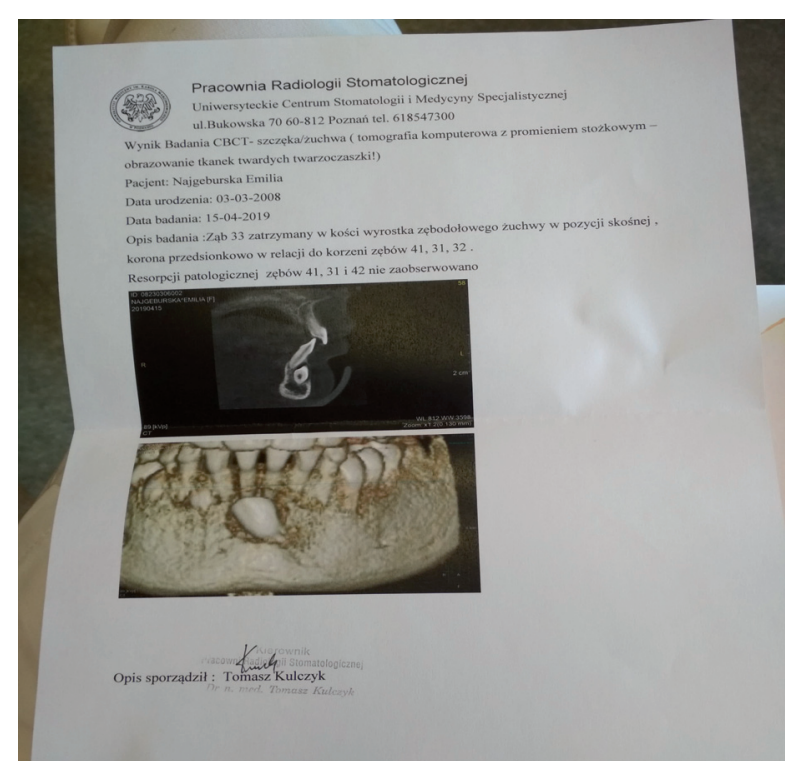

Rycina 2. CBCT przed rozpoczęciem terapii ortodontycznej

Figure 2. $C B C T$ before orthodontic treatment

\section{Oświadczenia}

\section{Oświadczenie dotyczące konfliktu interesów}

Autorzy deklarują brak konfliktu interesów w autorstwie oraz publikacji pracy.

\section{Źródła finansowania}

Autorzy deklarują brak źródeł finansowania. 


\section{Piśmiennictwo}

[1] Aktan AM, Kara S, Akgünlü F, Malkoç S. The incidence of canine transmigration and tooth impaction in a Turkish subpopulation. Eur J Orthod. 2010;32(5):57-581.

[2] Alaejos-Algarra C, Berini-Aytes L, Gay-Escoda C. Transmigration of mandibular canines: report of six cases and review of the literature. Quintessence Int. 1998;29(6):395-398.

[3] Mupparapu M. Patterns of intra-osseous transmigration of mandibular canines, review of literature and a report of nine additional cases. Dento Radio. 2002;31(6):355-60.

[4] Howard R. D. The anomalous mandibular canine. $\mathrm{Br}$ J Orthod. 1976;3(2):117-121.

[5] Shapira Y, Kuftinec MM. Intrabony migration of impacted teeth. Angle Orthod. 2003;73(6):738-743.

[6] Cavuoti S, Matarese G, Isola G, Abdolreza J, Femiano F, Perillo L. Combined orthodontic-surgical management of a transmigrated mandibular canine. The Angle Orthod. 2016;86(4):681-691.

[7] Fortuna T, Reboucas D, Neto WC, Cerqueira LS, Soares Zerbinati LP, Freitas de Assis A. Transmigrant impacted mandibular canine: A case report. Brazilian Dental Science. 2017;20(2):132.
[8] Wieczorek K, Łobacz M, Berger M, Litko M, Rahnama M. Extraction of a transmigrated mandibular canine and postextraction space augmentation with autologous lowmolecular-weight dentin graft. Case report. Orthodontic Forum. 2019;14(3):228-236.

[9] Verma SL, Sharma VP, Singh GP. Management of a transmigrated mandibular canine. J Orthod Sci. 2012;1(1):23-28.

Zaakceptowano do edycji: 2020-10-06 Zaakceptowano do publikacji: 2020-10-06

\section{Adres do korespondencji:}

Katedra i Klinika Ortopedii Szczękowej

i Ortodoncji,

Uniwersytet Medyczny im. Karola Marcinkowskiego w Poznaniu

ul. Bukowska 70

60-812 Poznań

tel.: 618547068

e-mail: klinika.ortodoncji@ump.edu.pl 